\title{
ANALISIS KONTINGENSI PADA SISTEM TENAGA LISTRIK SULAWESI UTARA - GORONTALO
}

\author{
Ekoriskiyanto $^{1}$, Yasin Mohamad ${ }^{2}$, Ervan Hasan Harun ${ }^{3}$. \\ 1,2,3 Jurusan Teknik Elektro, Fakultas Teknik, Universitas Negeri Gorontalo
}

\begin{abstract}
Abstrak
This research aims to determine changes in the stress conditions of each bus and the power flow changes that occur in the North Sulawesi Gorontalo transmission system when there is a transmission line being released based on power flow calculations by comparing the simulation results to the normal conditions and contingency conditions of the transmission line. The methods used are the Newton-Rapshon power flow method and the Line MVA Performance Index method $\left(P I_{M V A}\right)$. Performance Index calculations are performed to show the influence of contingency on the system using the results of the power flow analysis. Power flow simulation is carried out on the transmission system $150 \mathrm{kV}$ and $66 \mathrm{kV}$ Sulawesi Utara - Gorontalo with various load conditions namely low load, medium load, and peak load.
\end{abstract}

Keywords: Analisis Kontingensi, Performance Indeks, aliran daya, metode Newton-Rapshon

\section{PENDAHULUAN}

Sistem tenaga listrik bertujuan untuk menyediakan dan menyalurkan energi listrik secara andal dan terus menerus kepada beban. Bila ditinjau secara umum, keandalan sistem tenaga listrik didefinisikan sebagai kemampuan sistem untuk memberikan pasokan tenaga listrik yang cukup dengan kualitas yang memuaskan. Oleh karena itu, dalam pengoperasian sistem tenaga listrik perlu strategi sebaik-baiknya agar sistem tetap mampu bertahan akibat adanya kendalakendala yang ada, termasuk gangguan karena terjadi lepasnya salah satu saluran transmisi.

Gangguan yang berupa lepasnya salah satu elemen sistem adalah gangguan yang sepenuhnya tidak dapat dihindari. Hal inilah dapat mengubah komponen - komponen ketenagalistrikan. Lepasnya elemen sistem dapat terjadi karena gangguan atau karena pemeliharaan. Sistem interkoneksi Sulawesi Utara - Gorontalo merupakan sistem interkoneksi antara pusat pembangkit satu dengan pusat pembangkit lainnya dengan harapan pasokan tenaga listrik masih tetap berjalan apabila salah satu pembangkit mengalami gangguan. Sistem ini memberikan pelayanan tenaga listrik di provinsi Sulawesi Utara dan provinsi Gorontalo yang terhubung melalui Saluran Udara Tegangan Tinggi 150 $\mathrm{kV}$ dan $66 \mathrm{kV}$. Namun, gangguan lepasnya salah satu saluran transmisi mungkin terjadi, sehingga dapat mengganggu proses penyaluran tenaga listrik. Dengan demikian perlu dilakukan analisis kontingensi untuk mengetahui dampak dari lepasnya salah satu saluran transmisi.

Pada penelitian ini, dilakukan analisis kontingensi sistem interkoneksi Sulawesi Utara - Gorontalo yang terhubung melalui sistem transmisi $150 \mathrm{kV}$ dan $66 \mathrm{kV}$, dimana perhitungannya akan melihat batasan-batasan operasi seperti tegangan bus yang melanggar batasan yang ditetapkan dan kapasitas pembebanan saluran. Hasil akhir dari analisis ini berupa menunjukkan saluran transmisi yang memiliki dampak terhadap keamanan operasi sistem tenaga listrik apabila terjadi gangguan pada lokasi saluran tersebut.

\section{METODE PENELITIAN}

\subsection{Studi Aliran Daya}

Studi aliran daya dilakukan untuk mendapatkan informasi mengenai aliran daya atau tegangan sistem dalam kondisi operasi tunak. Informasi ini sangat dibutuhkan guna mengevaluasi unjuk kerja sistem tenaga dan menganalisis kondisi pembangkitan maupun pembebanan. Analisis ini juga memerlukan informasi aliran daya dalam kondisi normal maupun darurat.

Di dalam studi aliran daya, bus-bus dibagi dalam 3 macam, yaitu :

a. Slack bus atau swing bus. Slack bus berfungsi untuk menyuplai kekurangan daya real P dan daya reaktif Q pada system . Parameter yang ditentukan adalah harga skalar $|\mathrm{V}|$ dan sudut fasanya $\theta$, sedangkan yang tidak diketahui adalah daya real $\mathrm{P}$ dan daya reaktif $\mathrm{Q}$. 
b. Voltage controlled bus atau bus generator. Parameter yang ditentukan adalah daya real $\mathrm{P}$ dan harga skalar tegangan |V |, sedangkan parameter yang tidak diketahui adalah daya reaktif $Q$ dan sudut fasanya $\theta$.

c. Load bus atau bus beban. Parameter yang ditentukan adalah daya real $\mathrm{P}$ dan daya reaktif $\mathrm{Q}$, sedangkan parameter yang tidak diketahui adalah harga skalar $|\mathrm{V}|$ dan sudut fasanya $\theta$.

\subsection{Pemodelan Sistem Tenaga Pemodelan Generator Sinkron}

Untuk analisis aliran daya, generator sinkron dimodelkan dengan sumber daya aktif tertentu dan tegangan terminal yang konstan jika limit pembangkitan daya reaktif tidak dilanggar. Pada bus referensi, generator dinyatakan dengan tegangan dan sudut fasa yang tetap.

Pada pemodelan ini, limit daya reaktif dapat diawasi. Ketika limit tersebut dilewati, maka tegangan terminal akan dibiarkan bervariasi dan daya reaktif ditahan pada nilai limitnya tersebut

\section{Pemodelan Saluran Transmisi}

Dalam sistem tenaga, saluran transmisi dapat dikelompokkan menjadi tiga kelompok, yaitu (Nofendra,2008):

- Saluran pendek (sampai dengan $80 \mathrm{~km}$ )

- Saluran menengah (antara $80 \mathrm{~km}$ sampai dengan $200 \mathrm{~km}$ )

- Saluran panjang (lebih dari $200 \mathrm{~km}$ ).

Pada pemodelan saluran pendek, kapasitansi shunt saluran dapat diabaikan sehingga dapat direpresentasikan dengan impedansi seri. Sedangkan untuk saluran menengah dan saluran panjang, dimodelkan dengan menggunakan rangkaian $\Pi$ ekivalen.

\section{Pemodelan Beban}

Model beban statis adalah model yang merepresentasikan daya aktif dan reaktif sebagai fungsi dari tegangan bus dan frekuensi. Respons beban statis terhadap perubahan tegangan dan frekuensi tercapai dengan cepat, sehingga cenderung kondisinya dalam keadaan tunak.

\section{Pemodelan Transformator}

Pada trafo daya, arus melalui reaktansi magnetisasi $(\mathrm{Xm})$ dan rugi inti besi $(\mathrm{Rm})$ jauh lebih kecil dibandingkan dengan arus beban, sehingga $X m$ dan $R$ dapat diabaikan. Dengan kata lain sirkuit eksitasi pada trafo daya dapat diabaikan, sehingga dimodelkan sebagai impedansi Z.

\subsection{Metode Newton - Rapshon}

Metode Newton-Rhapson menyelesaikan masalah aliran daya dengan menggunakan suatu set persamaan non linier untuk menghitung besarnya tegangan dan sudut fasa tegangan tiap bus.

Persamaan umum dari arus yang menuju bus $\mathrm{i}$ $I_{i}=V_{i} \sum_{j=1}^{n} Y_{i j} \cdot V_{j}$

Persamaan diatas bila ditulis dalam bentuk polar adalah :

$I_{i}=V_{i} \sum_{j=1}^{n}\left|Y_{i j}\right|\left|V_{j}\right| \angle \theta_{j}+\delta_{j}$

Daya kompleks pada bus i adalah :

$\boldsymbol{P}_{\boldsymbol{i}}-\boldsymbol{J} \boldsymbol{Q}_{\boldsymbol{i}}=\boldsymbol{V}_{\boldsymbol{i}}^{*} \boldsymbol{I}_{\boldsymbol{i}}$

sehingga dengan mensubsitusikan persamaan (2) ke persamaan (3) di atas didapatkan :

$\boldsymbol{P}_{i}-\boldsymbol{J} \boldsymbol{Q}_{i}=\left|\boldsymbol{V}_{\boldsymbol{i}}\right| \angle-\boldsymbol{\delta}_{i} \cdot \sum_{j=1}^{n}\left|\boldsymbol{Y}_{i j}\right|\left|\boldsymbol{V}_{j}\right| \angle \boldsymbol{\theta}_{j}+\boldsymbol{\delta}_{j} \ldots$

Nilai-nilai $\mathrm{P}$ dan $\mathrm{Q}$ dapat ditetapkan untuk semua bus kecuali slack bus dan memperkirakan besar dan sudut tegangan pada setiap bus kecuali slack bus yang mana besar dan sudut tegangan telah ditentukan. Nilai perkiraan ini akan digunakan untuk menghitung nilai $\mathrm{P}$ dan $\mathrm{Q}$ dengan menggunakan persamaan di atas, sehingga didapatkan :

$\Delta P=P^{\text {spec }}-P^{\text {calc }}$

$\Delta Q=Q^{\text {spec }}-Q^{\text {calc }}$

Pada slack bus nilai magnitude tegangan (V) dan sudut tegangan ( $\delta$ ) adalah tetap, sehingga tidak dilakukan perhitungan pada setiap iterasinya. Sedangkan pada generator bus, daya aktif $(\mathrm{P})$ dan magnitude tegangan (V) bernilai tetap. Sehingga hanya daya reaktif yang dihitung pada setiap iterasinya. Matrik Jacobian terdiri dari turunan parsial $\mathrm{P}$ dan $\mathrm{Q}$ terhadap masing-masing variabel dalam persamaan di atas. Dapat dituliskan sebagai berikut :

$\left[\begin{array}{l}\Delta P \\ \Delta Q\end{array}\right]=\left[\begin{array}{ll}J_{1} & J_{2} \\ J_{3} & J_{4}\end{array}\right]\left[\begin{array}{c}\Delta \delta \\ \Delta|V|\end{array}\right]$

Submatrik J1, J2, J3, J4 menunjukkan turunan parsial dari persamaan di atas terhadap $\delta$ dan $\mathrm{V}$ yang bersesuaian, dan secara matetatis dapat dituliskan sebagai berikut :

Nilai untuk elemen $\mathrm{J} 1$ adalah :

$\frac{\partial P_{i}}{\partial \delta_{i}}=\sum_{j \neq 1}^{n}\left|V_{i}\right|\left|V_{j}\right|\left|Y_{i j}\right| \operatorname{Sin}\left(\theta_{i j}-\delta_{i}+\delta_{j}\right)$. 
$\frac{\partial P_{i}}{\partial \delta_{j}}=-\left|V_{i}\right|\left|V_{j}\right|\left|Y_{i j}\right| \operatorname{Sin}\left(\theta_{i j}-\delta_{i}+\delta_{j}\right) j \neq 1 \ldots(9)$

Nilai untuk elemen $\mathrm{J} 2$ adalah :

$\frac{\partial P_{i}}{\partial\left|V_{i}\right|}=2\left|V_{i}\right|\left|Y_{i i}\right| \operatorname{Cos} \theta_{i i}+\sum_{j \neq 1}\left|V_{j}\right|\left|Y_{i j}\right| \operatorname{Cos}\left(\theta_{i j}-\delta_{i}+\right.$

$\left.\delta_{j}\right)$

$\frac{\partial P_{i}}{\partial\left|V_{j}\right|}=\left|V_{i}\right|\left|Y_{i j}\right| \operatorname{Cos}\left(\theta_{i j}-\delta_{i}+\delta_{j}\right) J \neq 1 \ldots$

Nilai untuk elemen J3 adalah :

$\frac{\partial Q_{i}}{\partial \delta_{i}}=\sum_{j \neq 1}\left|V_{i}\right|\left|V_{j}\right|\left|Y_{i j}\right| \operatorname{Cos}\left(\theta_{i j}-\delta_{i}+\delta_{j}\right) \ldots$

$\frac{\partial Q_{i}}{\partial \delta_{j}}=-\left|V_{i}\right|\left|V_{j}\right|\left|Y_{i j}\right| \operatorname{Cos}\left(\theta_{i j}-\delta_{i}+\delta_{j}\right) J \neq 1 \ldots$

Nilai untuk elemen $\mathrm{J} 4$ adalah :

$\frac{\partial Q_{i}}{\partial\left|V_{i}\right|}=-2\left|V_{i}\right|\left|Y_{i i}\right| \operatorname{Sin} \theta_{i i}+\sum_{j \neq 1}\left|V_{j}\right|\left|Y_{i j}\right| \operatorname{Sin}\left(\theta_{i j}-\delta_{i}+\right.$

$\left.\delta_{j}\right)$.. (14)

$\frac{\partial Q_{i}}{\partial\left|V_{j}\right|}=-\left|V_{i}\right|\left|Y_{i j}\right| \operatorname{Sin}\left(\theta_{i j}-\delta_{i}+\delta_{j}\right) J \neq 1 \ldots .$.

Setelah seluruh persamaan diselesaikan, maka nilai koreksi magnitude dan sudut tegangan ditambahkan ke nilai sebelumnya.

$\delta_{i}^{(k+1)}=\delta_{i}^{k}+\Delta \delta_{i}^{k}$

$\left|V_{i}^{(k+1)}\right|=\left|V_{i}^{k}\right|+\left|\Delta V_{i}^{k}\right|$

Proses iterasi kembali lagi ke proses awal dan hal ini terus diulangi sampai $\Delta P_{i}^{k}$ dan $\Delta Q_{i}^{k}$ untuk semua bus (selain slack bus) memenuhi harga toleransi yang diberikan (biasanya diambil $\leq 0.0001$ ).

Jadi iterasi akan selesai bila,

$\Delta P_{i}^{k} \leq 0.0001$

$\Delta Q_{i}^{k} \leq 0.0001$

\subsection{Analisis Kontingensi}

Kontingensi adalah suatu kejadian yang disebabkan oleh kegagalan atau pelepasan dari satu atau lebih generator dan atau transmisi. Istilah ini berkaitan erat dengan kemampuan suatu sistem tenaga listrik untuk melayani beban apabila terjadi gangguan pada salah satu komponennya. Analisis kontingensi dapat dibedakan menjadi dua yaitu analisis kontingensi tunggal (single contingencies) dan kontingensi jamak (multiple contingencies), analisis kontingensi tunggal terjadi, setelah salah satu saluran transmisi atau transformator atau generator dilepaskan yang kemungkinan direncanakan untuk perbaikan, penjadwalan operasi pemeliharaan rutin, maupun terpaksa karena kondisi cuaca, atau karena gangguan, sedangkan analisis kontingensi jamak adalah jika dua atau lebih saluran keluar atau jatuh karena gangguan secara serentak, atau jika sebuah saluran jatuh dan terjadinya gangguan unit pembangkit dalam memasok tenaga listrik ke beban.

Analisis kontingensi merupakan perhitungan yang digunakan untuk mengevaluasi pengaruh gangguan terhadap perubahan tegangan bus dan aliran daya saluran. Penganalisaan dilakukan dengan membandingkan aliran daya dalam kondisi normal dengan aliran daya dalam berbagai kondisi yang mungkin terjadi dalam sistem dimasa yang akan datang dengan melakukan berbagai kontingensi.

\subsection{Kuantitas Per-Unit}

Untuk mempermudah perhitungan atau analisa pada sistem tenaga listrik biasanya dipakai nilai-nilai dalam per-satuan (per-unit). Besaran per-unit didefenisikan sebagai berikut (Cahayati dan Nedi, 2008):

Per-unit $=\frac{\text { Besaran Yang Sesungguhnya }}{\text { Besaran Dasar }}$

Dengan demikian nilai dari besaran perunit merupakan nilai yang telah di normalisasikan terhadap besaran dasar yang telah dipilih. Terdapat empat besaran yang sering diperhitungkan di dalam menganalisis sistem tenaga listrik, yaitu : daya, tegangan, arus, dan impedansi. Dengan memilih dua buah besaran (misalnya daya dan tegangan) sebagai besaran dasar, secara langsung dapat diperoleh besaran-besaran dasar yang lain. Dalam perhitungan sistem tenaga listrik, tegangan nominal saluran serta peralatan selalu diketahui, oleh sebab itu dipilih sebagai besaran dasar. Besaran dasar yang kedua yang biasa dipilih sebagai pedoman adalah daya (MVA).

Berikut rumus-rumus untuk macammacam kuantitas:

Arus dasar, $\boldsymbol{A}=\frac{\text { DasarkVA }_{\mathbf{3}}}{\sqrt{3} \times \text { TeganganDasar, } \boldsymbol{k V A}_{L L}} \ldots \ldots .$.

Impedansi Dasar, $\mathbf{\Omega}=\frac{\left(\text { Tegangan Dasar } \boldsymbol{k V A} A_{L L}\right)^{2}}{\text { Dasar } \boldsymbol{M V A} \mathbf{A}_{36}}$.(21)

Impedansi Per Unit,$=\frac{\text { Impedansi Sebenarnya }, \mathbf{\Omega}}{\text { Impedansi Dasar }, \mathbf{\Omega}}$

Tegangan Sebenarnya, $\boldsymbol{k} \boldsymbol{V}=$

Tegangan Per Unit $x$ Tegangan Dasar, $\boldsymbol{k} \boldsymbol{V}$...

\subsection{Metode Line MVA Performance Index}

Kondisi beban sangat berpengaruh terhadap aliran daya pada saluran yang berbeda dan performa sistem. Line MVA Performance Index (PI $\left.\boldsymbol{M V A}_{\boldsymbol{M}}\right)$ adalah metode 
untuk mengindikasikan peringkat overloads pada saluran. Didefinisikan sebagai berikut:

$P I_{M V A}=\sum_{i=1}^{N_{L}} \frac{W_{L i}}{M} \cdot\left(\frac{\text { Si post }}{\text { Si Max }}\right)^{M}$

Keterangan :

$\boldsymbol{P} \boldsymbol{I}_{M V A}=$ Performance Index

Si post = Daya yang mengalir pada suatu saluran setelah terjadi kontingensi (MVA)

Si $\boldsymbol{M a x}=$ kemampuan MVA daya hantar (rating MVA)

$\boldsymbol{N}_{\boldsymbol{L}} \quad=$ Jumlah saluran dalam sistem tenaga listrik

$\boldsymbol{W}_{L i}=$ Faktor real non-negative weighting $(=1)$

$\boldsymbol{M}=$ Urutan eksponen untuk penalty function $(=2)$

\section{METODE PENELITIAN}

Pada penelitian ini akan dilihat perubahan kondisi tegangan tiap bus dan perubahan aliran daya yang terjadi pada sistem transmisi Sulawesi Utara - Gorontalo ketika terjadi lepasnya salah satu saluran transmisi berdasarkan perhitungan aliran daya. Kondisi tegangan dilihat berdasarkan Aturan Jaringan Sistem Tenaga Listrik Sulawesi (Grid Code Sulawesi) yakni batas normal $+5 \%$ atau $-10 \%$ dari tegangan nominal dan juga akan dilihat pembebanan pada tiap saluran berdasarkan perubahan aliran daya. Objek pada penelitian ini adalah sistem transmisi $150 \mathrm{kV}$ dan $66 \mathrm{kV}$ SulutGo. Metode yang digunakan adalah metode aliran daya Newton-Rapshon.

Data yang digunakan dalam penelitian ini adalah data sekunder berupa data saluran, data beban, data bus pada sistem interkoneksi 150 $\mathrm{kV}$ dan $66 \mathrm{kV}$ Sulawesi Utara - Gorontalo. Data ini merupakan data operasional pada bulan Mei 2017. Data tersebut diperoleh dari Area Penyaluran dan Pengatur Beban (AP2B) Sistem Minahasa, Tomohon Sulawesi Utara. Penelitian dilakukan melalui beberapa tahapan sebagai berikut :

1. Studi Literatur

Studi literatur dimaksudkan untuk mempelajari berbagai sumber referensi atau teori, (buku, paper, jurnal ilmiah ) yang berkaitan dengan penelitian analisa kontingensi yang menggunakan Metode Newton Rapshon untuk perhitungan aliran daya.

2. Pengambilan Data

Pengumpulan data dilakukan di Sistem Tenaga Listrik Sulawesi Utara dan Gorontalo yaitu Area Penyaluran dan Pengatur Beban
(AP2B) Sistem Minahasa, Tomohon Sulawesi Utara.

3. Simulasi Sistem

Simulasi ini dilakukan bertujuan untuk melihat batasan-batasan seperti tegangan bus dan kapasitas pembebabanan saluran pada sistem transmisi Sulawesi Utara-Gorontalo ketika terjadi lepasnya salah satu saluran transmisi. Analisa kontingensi yang dilakukan adalah lepasnya salah satu saluran transmisi yang tidak mengubah jumlah bus dari sistem. Perhitungan Performance Index dilakukan berdasarkan dari hasil perhitugan aliran daya Newton-Rapshon. Penganalisaan aliran daya pada penelitian ini dilakukan dengan bantuan software Matlab melalui toolbox MatPower 6.0

\section{HASIL DAN PEMBAHASAN}

Bagian ini akan dipaparkan hasil perhitungan dengan membandingkan simulasi aliran daya pada keadaan normal dan keadaan kontingensi yang dipilih, serta hasil perhitungan Performansi Indeks. Sistem disimulasikan dalam berbagai kondisi beban pada tanggal 30 Mei 2017 yaitu beban rendah (waktu beban pagi pukul 05.00 WITA), beban sedang (waktu beban siang pukul 14.00 WITA), dan beban puncak (waktu beban malam pukul 18.30 WITA). Faktor daya pada beban sebesar 0,95.

\subsection{Kondisi Beban Rendah}

\subsubsection{Kontingensi Saluran GI Lopana -GIS Teling}

Untuk kondisi pertama dilakukan simulasi pada kondisi beban rendah, dimana sistem hanya dibebani 228,33 MW. Skenario kontingensi pertama terjadi pada saluran trnasmisi GI Lopana - GIS Teling. Gambar 4.1 menunjukkan perbandingan profil tegangan sistem pada keadaan normal dan saat kontingensi terjadi. 


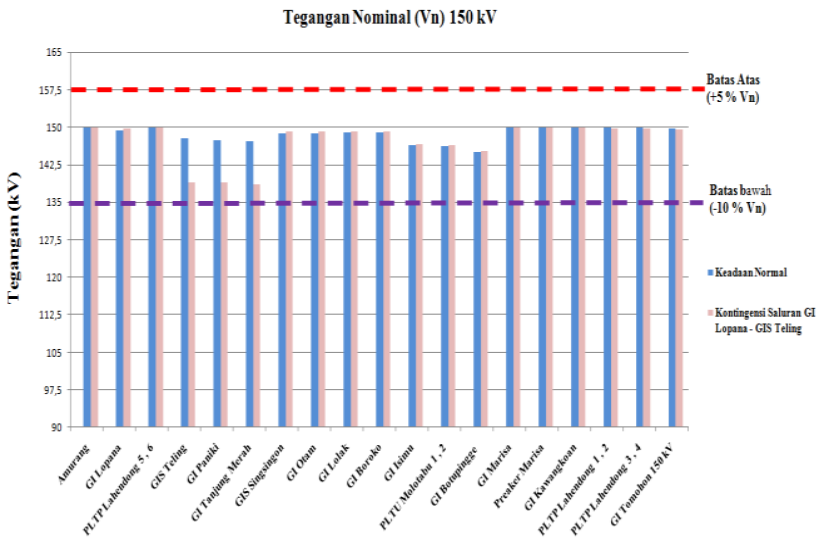

Gambar 4.1 Tegangan Bus $150 \mathrm{kV}$ keadaan normal dan kontingensi Saluran GI Lopana GIS Teling Kondisi Beban Rendah

\subsubsection{Kontingensi Saluran}

PLTP Lahendong 3,4 - GI Tomohon

Skenario kontingensi kedua terjadi pada saluran transmisi PLTP Lahendong3,4 - GI Tomohon. Gambar 4.2 menunjukkan perbandingan profil tegangan sistem pada keadaan normal dan saat kontingensi terjadi.

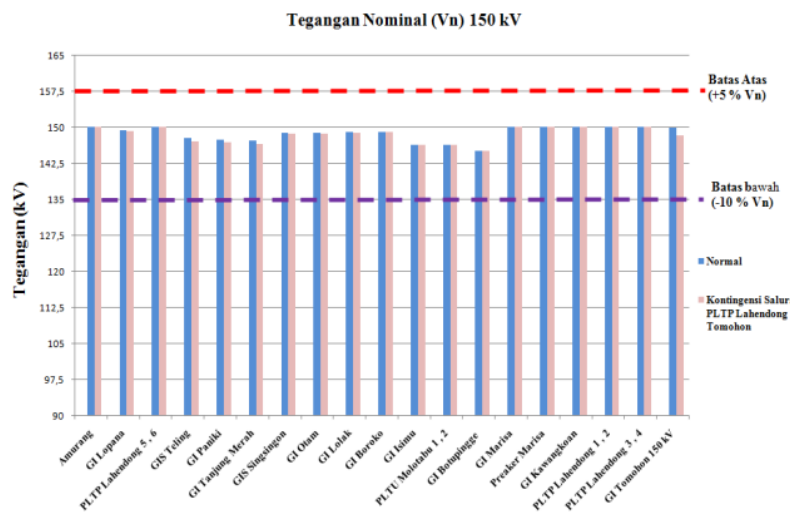

Gambar 4.2 Tegangan Bus $150 \mathrm{kV}$ keadaan normal dan kontingensi Saluran PLTP Lahendong 3,4 - GI Tomohon Kondisi Beban Rendah

\subsection{Kondisi Beban Sedang}

\subsubsection{Kontingensi Saluran GI Lopana -GIS} Teling

Untuk kondisi kedua dilakukan simulasi pada kondisi beban sedang, dimana sistem hanya dibebani 269,48 MW. Skenario kontingensi pertama terjadi pada saluran transmisi GI Lopana - GIS Teling. Gambar 4.3 menunjukkan perbandingan profil tegangan sistem pada keadaan normal dan saat kontingensi terjadi

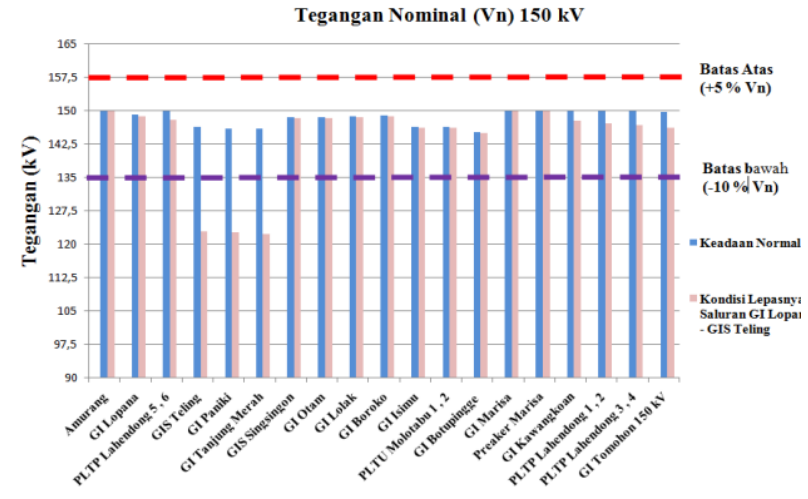

Gambar 4.3 Tegangan Bus $150 \mathrm{kV}$ keadaan normal dan kontingensi Saluran GI Lopana GIS Teling Kondisi Beban Sedang

\subsubsection{Kontingensi Saluran PLTP} Lahendong 3,4 - GI Tomohon

Skenario kontingensi kedua terjadi pada saluran transmisi PLTP Lahendong3,4 - GI Tomohon. Setelah dilakukan simulasi daya, maka didapat hasil tegangan pada masingmasing bus . Gambar 4.4 menunjukkan perbandingan profil tegangan sistem pada keadaan normal dan saat kontingensi terjadi

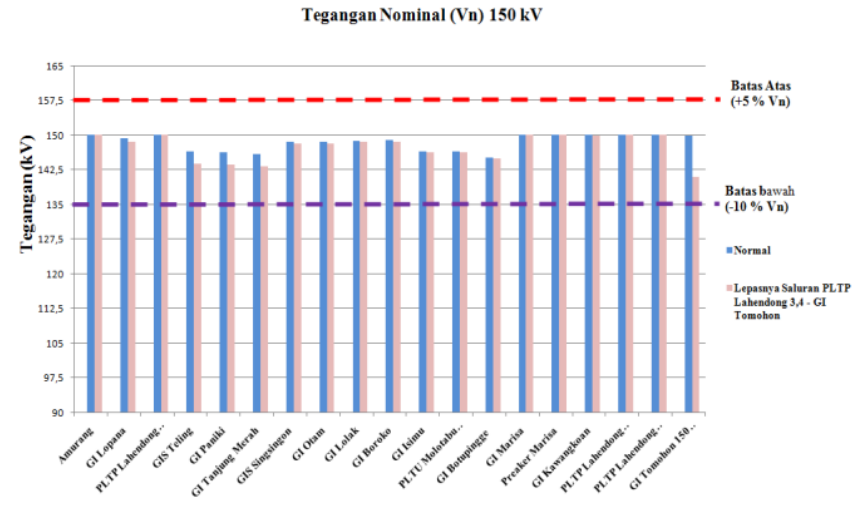

Gambar 4.4 Tegangan Bus $150 \mathrm{kV}$ keadaan normal dan kontingensi Saluran PLTP Lahendong 3,4 - GI Tomohon Kondisi Beban Sedang

\subsection{Kondisi Beban Puncak}

\subsubsection{Kontingensi Saluran GI Lopana -GIS Teling}

Untuk kondisi ketiga dilakukan simulasi pada kondisi beban puncak, dimana sistem hanya dibebani 325,88 MW. Skenario kontingensi pertama terjadi pada saluran trnasmisi GI Lopana - GIS Teling. Gambar 4.5 menunjukkan perbandingan profil tegangan sistem pada keadaan normal dan saat kontingensi terjadi. 


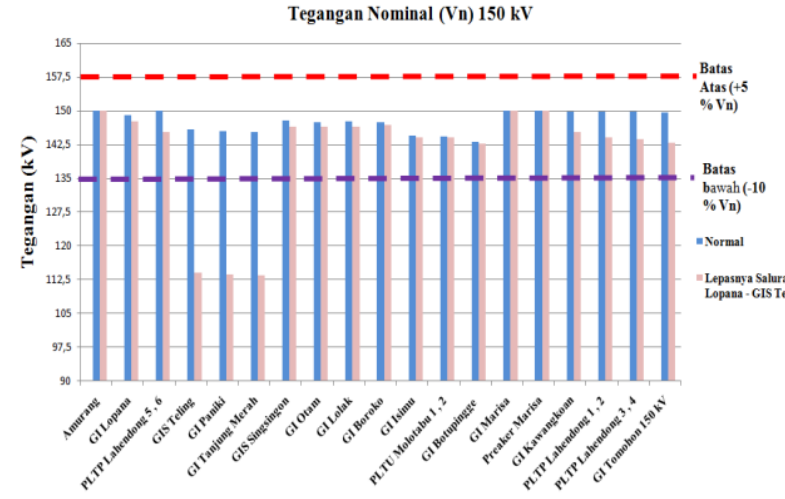

Gambar 4.5 Tegangan Bus $150 \mathrm{kV}$ keadaan normal dan kontingensi Saluran GI Lopana GIS Teling Kondisi Beban Puncak

\subsubsection{Kontingensi Saluran PLTP Lahendong 3,4 - GI Tomohon}

Skenario kontingensi kedua terjadi pada saluran transmisi PLTP Lahendong3,4 - GI Tomohon. Setelah dilakukan simulasi daya, maka didapat hasil tegangan pada masingmasing bus . Gambar 4.6 menunjukkan perbandingan profil tegangan sistem pada keadaan normal dan saat kontingensi terjadi.

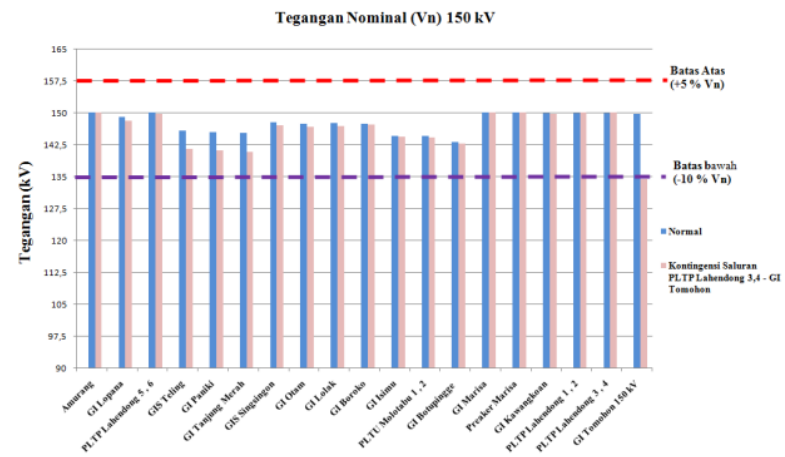

Gambar 4.6 Tegangan Bus 150 kV Keadaan Normal Dan Kontingensi Saluran PLTP Lahendong 3, 4 - GI Tomohon Kondisi Beban Puncak

\subsection{Perhitungan Line MVA Performance Indeks}

Pada sistem interkoneksi Sulwesi Utara Gorontalo terdapat data penyaluran yaitu saluran transmisi dan trafo IBT yang melayani seluruh pembangkit untuk menyalurkan aliran daya ke seluruh bus beban. Dalam penelitian ini, kontingensi yang dilakukan adalah lepasnya salah satu saluran transmisi yang tidak mengubah jumlah bus sistem. Kondisi lepasnya salah satu saluran transmisi yang akan terjadi berdasarkan batasan masalah, kemungkinan sebanyak 22 kasus. Pada tabel
4.1, 4.2, 4.3 merupakan hasil perhitungan $\boldsymbol{P I}_{M V A}$ saat beban puncak, beban sedang dan beban rendah pada masing-masing kasus berdasarkan persamaan (24)

Tabel 4.1 Urutan Kontingensi Saluran Transmisi Menggunakan Metode Line MVA Performance Index $\left(\boldsymbol{P I}_{\boldsymbol{M V A}}\right)$ Kondisi Beban Puncak

\begin{tabular}{|c|c|c|}
\hline No & Kasus Kontingensi & $P I_{M V A}$ \\
\hline 1 & GI Lopana - GIS Teling & 2,268999038 \\
\hline 2 & PLTP Lhdg 3,4 - GI Tomohon & 1,415854016 \\
\hline 3 & PLTP Lhdg 1,2 - PLTP Lhdg 3,4 & 0,961052144 \\
\hline 4 & GI Lopana - GIS Singsingon & 0,790787736 \\
\hline 5 & GI Isimu - GI Marisa & 0,691510789 \\
\hline 6 & GI Kawangkoan-PLTP Lhdg 1,2 & 0,687599783 \\
\hline 7 & GI Ranomout - GI Sawangan & 0,665669428 \\
\hline 8 & GI Telin - GI Ranomout & 0,66220683 \\
\hline 9 & GI Teling - GI Tomohon & 0,65228256 \\
\hline 10 & GI Sawangan - GI Tonselama & 0,630143217 \\
\hline 11 & GI Tomohon - GI Tonsealama & 0,624742177 \\
\hline 12 & GI Buroko - GI Marisa & 0,619454627 \\
\hline 13 & GI Ismu - GI Botupingge & 0,616233678 \\
\hline 14 & GI Buroko - GI Isimu & 0,612775982 \\
\hline 15 & GI Lopana - GIS Otam & 0,612739175 \\
\hline 16 & PLTU Molotabu -GI Botupingge & 0,604910954 \\
\hline 17 & GI Bitung - GI MSM & 0,604209404 \\
\hline 18 & GI Lopana - GI Kawangkoan & 0,597018515 \\
\hline 19 & GI Bitung - GI Likupang & 0,594404871 \\
\hline 20 & GI Isimu - PLTU Molotabu & 0,592042489 \\
\hline 21 & GIS Singsingon - GI Otam & 0,591358062 \\
\hline 22 & GI MSM - GI Likupang & 0,580372102 \\
\hline
\end{tabular}

Tabel 4.2 Urutan Kontingensi Saluran Transmisi Menggunakan Metode Line MVA Performance Index $\left(\boldsymbol{P I}_{\boldsymbol{M V A}}\right)$ Kondisi Beban Sedang

\begin{tabular}{|c|l|c|}
\hline No & \multicolumn{1}{|c|}{ Kondisi Kasus } & $\boldsymbol{P I}_{\boldsymbol{M V A}}$ \\
\hline 1 & GI Lopana - GIS Teling & 1,683449932 \\
\hline 2 & PLTP Lhdg 3,4 - GI Tomohon & 0,945343323 \\
\hline 3 & PLTP Lhdg 1,2 - PLTP Lhdg 3,4 & 0,631544935 \\
\hline 4 & GI Lopana - GI Kawangkoan & 0,527985024 \\
\hline 5 & GI Teling - GI Tomohon & 0,519860261 \\
\hline 6 & GI Isimu - GI Marisa & 0,512073501 \\
\hline 7 & GI Ranomout - GI Sawangan & 0,511514378 \\
\hline
\end{tabular}




\begin{tabular}{|c|l|c|}
\cline { 2 - 3 } 8 & GI Buroko - GI Marisa & 0,478589485 \\
\hline 9 & GI Telin - GI Ranomout & 0,466680925 \\
\hline 10 & GI Sawangan - GI Tonselama & 0,459492677 \\
\hline 11 & GI Kawangkoan-PLTP Lhdg 1,2 & 0,458266471 \\
\hline 12 & GI Bitung - GI MSM & 0,453717601 \\
\hline 13 & GI Ismu - GI Botupingge & 0,452497189 \\
\hline 14 & GI Tomohon - GI Tonsealama & 0,449800198 \\
\hline 15 & PLTU Molotabu -GI Botupingge & 0,447606621 \\
\hline 16 & GI Bitung - GI Likupang & 0,444041019 \\
\hline 17 & GI Lopana - GIS Singsingon & 0,439603524 \\
\hline 18 & GI Lopana - GIS Otam & 0,439187682 \\
\hline 19 & GI Isimu - PLTU Molotabu & 0,437800613 \\
\hline 20 & GI MSM - GI Likupang & 0,43765028 \\
\hline 21 & GI Buroko - GI Isimu & 0,437263758 \\
\hline 22 & GIS Singsingon - GI Otam & 0,433628286 \\
\hline
\end{tabular}

Berdasarkan perhitungan $\boldsymbol{P I}_{\boldsymbol{M V A}}$ pada tabel 4.1, 4.2, 4.3 dapat diklasifikasikan bahwa saluran GI Lopana - GIS Teling adalah saluran yang paling berpengaruh pada sistem ketika lepas, karena memilki nilai PI yang besar, terutama pada saat beban puncak. Nilai PI merupakan representasi tingkat keparahan yang ditimbulkan oleh suatu kasus tanpa memberikan informasi tentang jumlah, letak, atau besarnya saluran yang overload dan atau bus yang undervoltage. Makin besar nilai PI, makin besar pula dampak dari lepasnya suatu saluran transmisi dibandingkan saluran yang lain.

\section{KESIMPULAN}

Berdasarkan hasil penelitian yang dilakukan dengan simulasi aliran daya menggunakan metode Newton-Rapshon pada sistem transmisi Sulawesi Utara-Gorontalo, maka dapat disimpulkan sebagai berikut :

Tabel 4.3 Urutan Kontingensi Saluran Transmisi Menggunakan Metode Line MVA Performance Index $\left(\boldsymbol{P} \boldsymbol{I}_{\boldsymbol{M V A}}\right)$ Kondisi Beban Rendah

\begin{tabular}{|c|l|c|}
\hline No & \multicolumn{1}{|c|}{ Kondisi Kasus } & $\boldsymbol{P I}_{\boldsymbol{M V A}}$ \\
\hline 1 & GI Lopana - GIS Teling & 0,754463073 \\
\hline 2 & GI Lopana - GI Kawangkoan & 0,615706114 \\
\hline 3 & PLTP Lhdg 3,4 - GI Tomohon & 0,447091777 \\
\hline 4 & GI Isimu - GI Marisa & 0,342904871 \\
\hline 5 & GI Buroko - GI Marisa & 0,314176093 \\
\hline 6 & GI Ranomout - GI Sawangan & 0,308286552 \\
\hline 7 & PLTP Lhdg 1,2 - PLTP Lhdg 3,4 & 0,294174821 \\
\hline 8 & GI Ismu - GI Botupingge & 0,290347675 \\
\hline 9 & GI Teling - GI Tomohon & 0,288973511 \\
\hline 10 & GI Kawangkoan-PLTP Lhdg 1,2 & 0,284609721 \\
\hline 11 & GI Bitung - GI MSM & 0,283420404 \\
\hline 12 & GI Telin - GI Ranomout & 0,28138774 \\
\hline 13 & PLTU Molotabu-GI Botupingge & 0,279904724 \\
\hline 14 & GI Bitung - GI Likupang & 0,275073899 \\
\hline 15 & GI Sawangan - GI Tonselama & 0,274639316 \\
\hline 16 & GI Lopana - GIS Otam & 0,273915665 \\
\hline 17 & GI Buroko - GI Isimu & 0,27351063 \\
\hline 18 & GI Isimu - PLTU Molotabu & 0,269548455 \\
\hline 19 & GI MSM - GI Likupang & 0,269169249 \\
\hline 20 & GIS Singsingon - GI Otam & 0,267058209 \\
\hline 21 & GI Tomohon - GI Tonsealama & 0,266691142 \\
\hline 22 & GI Lopana - GIS Singsingon & 0,265993195 \\
\hline
\end{tabular}

1. Kontingensi saluran trasnsmisi pada sistem interkoneksi Sulawesi Utara - Gorontalo menyebabkan penurunan tegangan pada beberapa bus.

a. Kontingensi saluran trasnsmisi GI Lopana - GIS Teling pada saat beban sistem 228,33 MW, tidak mengakibatkan besaran tegangan melewati batas tegangan $(<90 \%$ Tegangan Nominal), saat beban sistem 269,48 MW, 6 bus $66 \mathrm{kV}$ dan 2 bus 150 $\mathrm{kV}$ melewati batas tegangan yang ditetapkan, sedangkan pada saat beban sistem 325,88 MW, 11 bus $66 \mathrm{kV}, 2$ bus $30 \mathrm{kV}$, dan 3 bus $150 \mathrm{kV}$ melewati batas tegangan yang ditetapkan.

b. Kontingensi saluran trasnsmisi PLTP Lahenodng 3,4 - GI Tomohon saat kondisi beban sistem 228,33 MW dan 269,48 MW, tidak mengakibatkan besaran tegangan melewati batas tegangan ( $<90 \%$ Tegangan Nominal), sedangkan pada kondisi beban sistem $325,88 \mathrm{MW}, 7$ bus $66 \mathrm{kV}$, dan 1 bus $150 \mathrm{kV}$ melewati batas tegangan yang telah ditetapkan.

2. Kondisi aliran daya saat kontingensi saluran transmisi berubah, sehingga pembebanan pada saluran transmisi dan IBT $(150 / 66 \mathrm{kV})$ meningkat.

a. Kontingensi saluran transmisi GI Lopana - GIS Teling pada saat kondisi beban sistem 228,33 MW, IBT masih 
dalam keadaan aman. Saat kondisi beban sistem 269,48 MW, pembebanan pada IBT Tomohon 126,917 MVA (overload) dengan presentase 105,76 $\%$. Pada kondisi beban sistem 325,88 MW, pembebanan pada IBT Tomohon sebesar 153,631 MVA (overload) dengan presentase $128,03 \%$ serta IBT Teling sebesar 56,387 MVA dengan presentase 93,98\% dan pembebanan semua saluran transmisi dalam keadaan aman.

b. Kontingensi saluran transmisi PLTP Lahendong 3,4 - GI Tomohon mengakibatkan suplai daya dari sisi tegangan $150 \mathrm{kV}$ ke $66 \mathrm{kV}$ hanya disuplai melalui IBT Teling dengan perubahan nilai pembebanan yang berbeda pada tiap kondisi. Pada kondisi beban sistem 228,33 MW, pembebanan pada IBT Teling sebesar 35,145 MVA dengan presentase $58,58 \%$. Pada kondisi beban sistem 269,48 MW, pembebanan pada IBT Teling sebesar 63,82 MVA (overload) dengan presentase 106,37 \%. Pada kondisi beban sistem 325,88 MW, pembebanan pada IBT Teling sebesar 82,521 MVA (overload) dengan presentase 137,51\%

3. Berdasarkan perhitungan $\boldsymbol{P I}_{\boldsymbol{M V A}}$ diketahui bahwa pada kondisi beban 325,88 MW, nilai PI terbesar yaitu 2,268999038 pada saluran GI Lopana - GIS Teling, dan nilai PI terkecil yaitu 0,580372102 pada saluran GI MSM - GI Likupang. Pada kondisi beban 269,48 MW, nilai PI terbesar yaitu 1,683449932 pada saluran GI Lopana GIS Teling, dan nilai PI terkecil yaitu 0,433628286 pada saluran GI MSM - GI Likupang. Pada kondisi beban 228,33 MW, nilai PI terbesar yaitu 0,754463073 pada saluran GI Lopana - GIS Teling, dan nilai PI terkecil yaitu 0,265993195 pada saluran GI Lopana - GIS Singsingon .

\section{Daftar Pustaka}

Amin, N. 2011. Perbandingan Metode GaussSiedel Dan Metode Newton-Raphson Dalam Solusi Aliran Daya. Jurnal SMARTek, Vol. 9 No. 3:212-222. Universitas Tadulako. Palu.

Cahayati, dan O. Nedi. 2008. Analisis Kontingensi Sistem Tenaga Listrik Dengan menggunakan Power World Simulator (Aplikasi SUTT 150 $k V$ SumbagTeng). Jurnal Teknos-2k, Vol 8. No. 1 Januari : 212-222. Universitas Bung Hatta. Padang.
Harun, E.H. 2013.Bahan Ajar Analisis Sistem Tenaga Listrik (Revisi 2013). Jurusan Teknik Elektro, Fakultas Teknik, Universitas Negeri Gorontalo. Gorontalo.

Harun, E.H. dan T.I. Yusuf. 2012. Analisis Aliran Daya Pada Sistem Tenaga Listrik $150 \mathrm{kV}$ Gorontalo Menggunakan Metode Newton Rapshon. Laporan Penelitian PNBP 2012.

Hermawan, A. 2007. Analisis Kontingensi Pada Sistem Tenaga Listrik Dengan Metode Aliran Daya. Jurnal ELTEK, Volume 05 Nomor 01, April 2007 ISSN 1693-4024. Politeknik Negeri Malang.

Indriyani, R.D. 2017. Analisis Aliran Daya Pada Sistem Tenaga Listrik Sulawesi Utara Gorontalo Menggunakan Metode Fast Decoupled. Skripsi. Program studi Teknik Elektro, Jurusan Teknik Elektro, Fakultas Teknik, Universitas Negeri Gorontalo. Gorontalo.

Kevinamarta, D. dan T. Wrahatnolo. 2017. Evaluasi Keandalan Sistem Tenaga Listrik Subsistem Krian - Gresik $150 \mathrm{Kv}$ dengan Metode Analisis Kontingensi (N-1). Jurnal Teknik Elektro. Volume 06 Nomor 01:0-8 . Universitas Negeri Surabaya. Surabaya.

Mohamad, Y. 2007. Analisis Kontingensi Tunggal akibat putusnya Saluran Transmisi (Studi Kasus Sistem Jawa Tengah DIY). Jurnal Teknik, Volume 5 No.2 2007. Universitas Negeri Gorontalo. Gorontalo.

Nofendra, R. 2008. Penentuan Operasi Sistem Tenaga Listrik Menggunakan Performace Index (Kasus : Sistem Tenaga Sumbar-Riau ). Jurnal Teknik A No. 29 Vol.2 Thn. XV April 2008:80-90. Universitas Andalas Padang. Padang.

Palasworo, F.J. dan A. Widiantoro. 2018. Analisis Kontingensi Saluran Transmisi Pada Jaringan Transmisi 150 kV. Jurnal. Program Studi Teknik Elektro FT, UM-Surabaya. 